\title{
In-service and Pre-service Middle School Mathematics Teachers' Attitudes and Decisions Regarding Teaching Mathematics Using Mobile Phones
}

\author{
http://dx.doi.org/10.3991/ijim.v8i4.3721 \\ W. Daher 1,2 and N. Baya'a ${ }^{2}$ \\ ${ }^{1}$ An-Najah National University, Nablus, Palestine \\ ${ }^{2}$ Al-Qasemi Academic College of Education, Baqa, Israel
}

\begin{abstract}
Several researches examined students' mathematics learning using mobile phones, while very few researches examined mathematics teaching using this new educational tool. This research attempts to analyze in-service and preservice teachers' attitudes and decisions regarding mathematics teaching with mobile phones using activity theory. More specifically, three case studies are analyzed in this research: One concerns an in-service teacher who used mobile phones in her class, the second case study involves a pre-service teacher who collaborated with the in-service teacher to teach mathematics lessons using mobile phones, and the third case study is about 15 pre-service teachers who were observers of the experiment but did not use mobile phones in their teaching. We held one-hour semistructured interviews with the in-service teacher, with the leading pre-service teacher and with the group of other observer pre-service teachers. This happened three times during the academic year: at the beginning of the experiment, after three months and after it ended.
\end{abstract}

The research findings indicate that different factors have an impact on the attitudes and decisions of the teacher: history of the teacher using technologies in teaching, perceptions of the teacher using technologies in teaching, community's teacher, rules regulating the use of technologies in teaching mathematics, and division of labor. For example, questions as to who decides which technologies to use in the classroom and who should prepare the learning material for the students. Contradictions were identified in mathematics teachers' activity when utilizing mobile phones in their teaching. These contradictions hinder or slow such utilization. Community, especially its leading members, mediated and helped overcome the activity contradictions that arose throughout the experiment regarding the teaching processes in and/or out of the mathematics classroom.

Index Terms - middle school, mobile phones, mathematics teachers, teachers' attitudes, teachers' decisions.

\section{INTRODUCTION}

Mobile and wireless devices, especially mobile phones, have become increasingly common among young students. This provides new possibilities, opportunities, and challenges for education [1]. This is especially true for mathematics education, where students can use technologies to assist them to conceive independently and/or with the guide of the teacher mathematical concepts and rela- tions. The possibilities and opportunities regarding the use of mobile phones in mathematics education have been reported in the past few years in the literature, specifically regarding students' learning (see for example [2], [3]). We have also conducted our own research on different aspects of students' learning of mathematics using mobile phones. Specifically, we have studied different educational aspects of mathematics learning related to the mobile phone environment, where these aspects involved the behavioral aspect of students' learning ([4], [5]), the affective aspect of students' learning ([6], [7]; [8]), the social aspect ([9], $[10])$, the cognitive aspect ([8], [5]) and the metacognitive aspect of this learning [8].

In contrast to the substantial research conducted on students' learning with mobile phones (see for example the above examples on such research), little research has been done on issues related to teachers' instruction in a mobile phone environment. The current research attempts to address this issue by using activity theory as a conceptual framework to examine the attitude of teachers who use mobile phones in mathematics teaching. Three professional groups participated in this study: an in-service mathematics teacher; a leading pre-service teacher and a group of pre-service teachers. Using the framework of activity theory we try to understand what affects mathematics teachers' attitudes and decisions regarding the use of mobile phone in his/her instruction.

Though little research has been conducted on teaching using mobile phones, some research was done on using other mobile technologies in teaching. We describe some of this research below.

\section{LITERATURE REVIEW}

We will here present a review of the literature that deals with the educational aspects that concerns this research: M-learning and activity theory.

\section{A. M-learning}

Different aspects of using mobile technologies in education drew the attention of researchers who studied the impact of these technologies on education. Some of these issues are: the functions and advantages of using mobile technologies in education, factors that influence the use of mobile phones in education, constraints on using mobile technologies in education, and teachers' acceptance of these technologies. 
Researchers pointed out various advantages of using mobile technologies in education: enabling mobility, activity and interactivity, communicability, working meaningful content, motivating students, etc. Ref. [11] said that mobile technologies can improve the quality of education for they allow location independence, time independence and meaningful content. Furthermore, there is evidence that learners from diverse backgrounds may benefit from mobile technologies because of their emphasis on activity and interactivity as well as communication potentialities [12]. In addition, these technologies advance high-quality experiential learning [13]. Specifically for teachers, the communicational and the mobility facilities of the mobile technologies help monitor and guide students' learning, as well as facilitate group communication [14].

Ref. [14] described some of the mobile technologies' advantages in the case of integrating wireless LAN, wireless mobile learning devices, an electronic whiteboard, an interactive classroom server, and a resource and class management server to build a wireless technology enhanced classroom (WITEC) that supports everyday activities unobtrusively and seamlessly in classroom contexts. The actual use of WITEC revealed the advantages of the electronic system that includes mobile components. For example, in contrast with traditional classrooms, WITEC enabled the teacher and students to concentrate on teaching and learning itself rather than spend too much time and effort on tedious tasks. Furthermore, it helped the teacher to monitor each student's learning easily, which facilitated further guidance, as well as enabled engaging students in learning activities and facilitating students' group collaboration. We see then that wireless and mobile technology helped maintain the classical functions of computer technologies (for example facilitating computing tedious tasks) as well as providing more advanced functions in communication and collaboration.

Advantages of using mobile technologies in education encourage teachers' use of these technologies, where various reasons encourage teachers to use mobile technologies in their teaching [15]. Ref. [15] examined the reasons that encourage teachers' involvement with mobile technologies. They found four main reasons that the participating teachers mentioned as encouraging them to become involved in the mobile learning program: (1) keeping up to date with new technology and developing skills with technology; (2) using technology to motivate and engage students to learn better; (3) using technology to improve their teaching; and (4) having to be part of the program.

The use of mobile technologies in education is influenced by constraints that may slow the success of mobile technologies use in the classrooms [16], for example, the screen small size. Below we describe in more details some studies that treat teachers' use of mobile technologies.

Constraints on using mobile technologies in education influence the acceptance of these technologies by teachers. Ref. [11] conducted a study on the acceptance of mobile phones for teaching and learning with a group of preservice teachers in Hong Kong. The study showed that the majority of the respondents generally accepted the use of mobile phones for teaching and learning. Specifically, the participants somewhat agreed that mobile phones can improve education quality. In addition, their curiosity to use mobile phones for teaching and learning was high. Moreover, the respondents were interested in seeing mobile learning become part of their curriculum. Further- more, inhibiting factors perceived by the participants were small screens, text input, slow connectivity, high expenses, and the difficulty of mobile phone use.

The findings of the previous researches regarding the functions and advantages of using mobile technologies in education encouraged us to suggest mobile phones as a teaching tool to our mathematics pre-service teachers, as well as to one training teacher in the school where our preservice teachers were trained. Doing so, we were interested in verifying their attitudes and decisions regarding teaching mathematics with mobile phones. To analyze these attitudes and decisions we will use the activity theory framework.

\section{B. Activity theory as conceptual framework}

Activity theory is a cultural-historical theory of activity which was initiated by a group of Russian psychologists in the 1920s and 1930s. This approach was led by Lev Vygotsky (1896-1934) and his colleagues A.N. Leont'ev and A.R. Luria [17]. Ref. [18] says that activity theory, as initiated by Vygotsky, is centered around the idea of mediation which is represented in a triangular model in which the conditioned direct connection between stimulus (S) and response (R) was transcended by a complex mediated act, where Vygotsky's idea of cultural mediation of actions is commonly expressed as the triad of subject, object, and mediating artifact (Figure 1)

Ref. [19] proposed a model (Figure 2) that conceptualizes all purposeful human activity as the interaction of the elements: subject, object, tools, community, rules, and division of labor.

In what follows, we present a description of the elements that constitute the activity system (Ref. [20]).

In the model, the subject refers to the individual or group whose agency is chosen as the point of view in the analysis. The object refers to the 'raw material' or 'problem space' at which the activity is directed and which is intended to be transformed into an outcome with helping tools, where the tools can be physical and/or symbolic, external and/or internal. The community comprises multiple individuals and/or groups who share the same object and who construct themselves as distinct from other communities. The division of labor refers to both the horizontal division of tasks between the members of the com-
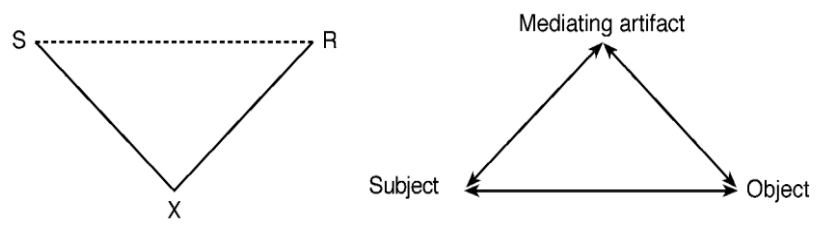

Figure 1. Vygotsky model of activity

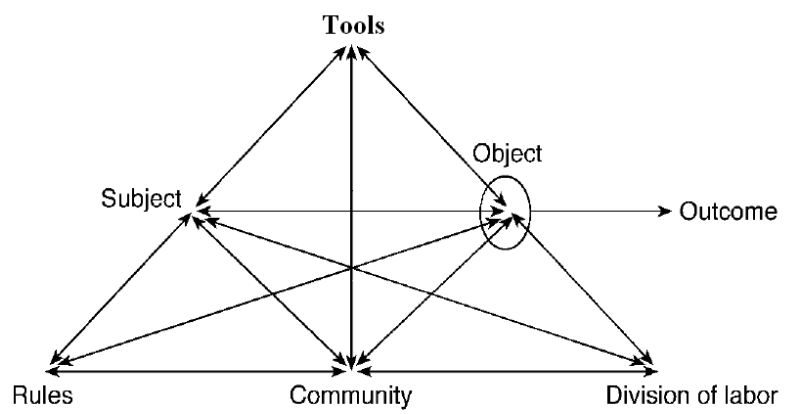

Figure 2. The structure of a human activity system 
munity and to the vertical division of power and status. Finally, the rules refer to the explicit and implicit regulations, norms and conventions that restrict actions and interactions within the activity system. The outcome is the result of the subject's involvement with the object of the activity, and which is influenced by the activity different elements. These elements of the activity theory fit the goal of analyzing teachers' attitudes and decisions due to the fact that they represent the conditions which influence teachers' work, especially when introducing a new technological tool to the classroom. We describe below these elements as related to our research.

The subject refers to the in-service teacher, the leading pre-service teacher or the rest of the pre-service teachers who were observers of teaching mathematics with mobile phones. The object refers to the mathematical educational environment (mathematics students, mathematics topic, mathematical activities, inter alia) which were to be developed into a mobile mathematical one, i.e. an environment that suits using mobile phones to teach and learn mathematics. The tool refers to the mobile phone which is suggested as a learning instrument in and/or out of the mathematics classroom. The community comprises the school in which the in-service/pre-service teacher teaches/practices, as well as the college in which the pre-service teacher learns, including the in-service /pre-service teacher herself. The division of labor refers to who should teach, who should prepare the learning activities needed to be used for learning mathematics with the mobile phone, who decides which tools to use in the mathematics classroom, who decides which mathematical material to cover in an academic year, etc. The rules refer to the norms and conventions regarding teaching/learning mathematics in the middle school/college or in the specific school/college, for example the question as to whether the computer or mobile phones should be used in the classroom or whether the in-service /pre-service teacher should prepare additional learning material for his/her students, inter alia. The outcome is the participants' decisions and attitudes towards mobile phone use in mathematics teaching.

\section{Contradictions in activity theory}

According to Ref. [21], as reported in Ref. [22], activity theory uses the term 'contradiction' to indicate a misfit within an element, between them, between different activities, or between different developmental phases of a single activity. For Ref. [19], if these contradictions are handled constructively they will lead to development of the activity, as well as to the learning outcome.

It is our intention to use activity theory to examine the in-service and pre-service teachers' instructional attitudes and decisions concerning the use of mobile phones in mathematics teaching (accepting these tools for mathematics teaching, when to use them, and how to use them). Doing so, we agree with the claim of Ref. [23] that when considering individual and institutional perspectives, as well as the evolution of technology use over time, activity theory and its contradictions provide a useful tool for examining various aspects of educational technology use. This claim is especially true when we consider teachers' attitudes and decisions regarding the use of mobile phones in the mathematics classroom because these attitudes and decisions are influenced by various factors which activity theory involves.

\section{Activity theory as a tool for analyzing educational processes}

Activity theory was used by researchers to identify the influences of the various aspects of an educational phenomenon. For example, Ref. [22] used activity theory to examine pedagogical, social, and technological issues in ICT integration process in Turkish classrooms. They concluded that the following aspects should be taken into consideration when carrying out ICT integration processes: organizational culture, changing roles of teachers and students with regards to ICT, inflexible time table curriculum, support of the school administration, mediation of the ICT coordinator, and collaboration among teachers.

Another research which examined a whole educational phenomenon using activity theory framework is that of Ref. [24] who used activity theory to study the potential and actual interrelationships between the constituent elements that comprise the complex process of music education. Welch concluded that there is much to be gained by exploring the principles of activity theory and applying them to the relationships and contributions between topdown and bottom-up perspectives in an educational process related to music.

Other researchers used one aspect of activity theory to analyze an educational phenomenon. For example, Ref. [25] attempted to explain how students' learning outcome evolved from their online learning experiences. The researcher found that there were three levels of contradictions that the students faced during their online learning: conflicting-object contradictions, inter-activity contradictions, and technology-related contradictions. He also found that contradictions may be invisible to some members who are part of the subject of the activity, but some members may have the capacity to identify the contradiction, yet they may not have the desire or motivation to make necessary changes to further learning and development within the activity. The researcher concluded that contradictions might not be resolved although they are visible.

Ref. [26] designed a qualitative collective case study to investigate how students revised after writing center conferences. To do the investigation, he used the activity theory framework. The study suggested that the object of the activity system of a writing conference should include the situation definitions that students hold about how to revise and how to participate in a writing conference.

Ref. [27], following Radford ([28], [29], [30]), analyzed mathematical learning at pre-apprenticeship training class for pipe-trades conducted at trade union run school in British Columbia, Canada. More specifically, an apprentice's thought processes in relation to reading a measuring tape was analyzed, together with his interactions with the researcher. This analysis, using Radford's approach to activity theory, considered activity theory as a lens to analyze individuals' activity and not only system's activity as suggested by Ref. ([18], [19], [31]). We will follow Ref. ([28], [29], [30])) and Ref. [27] in analyzing the attitudes and decisions of middle school in-service and preservice teachers regarding the integration of mobile phones into their mathematics teaching, i.e. we consider the current research participants (the in-service teacher, the leading pre-service teacher and each of the other preservice teachers) the individuals whose attitudes and deci- 
sions will be studied concerning mobile phone use in mathematics teaching.

\section{RESEARCH RATIONALE AND GOALS}

Using mobile tools in mathematics education is increasing, where this use changes the educational scene and enables out-of-class mathematics learning and teaching [32]. Researches who have studied the use of mobile tools in mathematics education have focused on students' learning rather than on teacher's instruction. This research attempts to shed light on this issue. To do so, we utilize activity theory as teacher's instruction is influenced by various factors that activity theory involves, such as school community and rules. In additions, activity theory can explain teachers' decisions in the light of the contradictions which they confront in their work.

The current research findings can help us establish insight into teachers' attitudes towards the use of new and mobile technologies in their instruction, as well as their decisions regarding the integration of these technologies into mathematics teaching.

\section{RESEARCH QUESTION}

For the purpose of this research the following research question was formulated:

How do the educational activity elements influence inservice and pre-service teachers' instructional attitudes and decisions concerning the use of mobile phones in mathematics teaching?

\section{RESEARCH DESIGN AND METHODOLOGY}

\section{A. Research setting and participants}

This research formed part of a larger research project in which we carried out an experiment that involved using mobile phones in teaching and learning mathematics. We carried out the project as an initiative in Al-Qasemi Academic College of Education, and obtained the approval of the research center in the college to conduct research, including interviewing the college pre-service teachers. Participation in the research was voluntary, and the respondents signed an informed consent.

The experiment took place in one middle school in Nazareth in the framework of the practical training of middle school pre-service teachers who majored in mathematics and computers in a teachers' college. The preservice teachers were in their third year of study and were required to use various technological tools in their teaching including the mobile phone. One pre-service teacher was responsible at the training school of the other preservice teachers' use of technology in their instruction. This responsibility meant three things: (1) the pre-service teachers could consult him regarding their use of technology in their instruction; (2) the leading pre-service teacher collaborated with one in-service teacher in the training school to prepare and teach lessons which integrated mobile phones in mathematics lessons; and (3) the leading pre-service teacher participated in the meetings held by the researchers regarding the use of technology of tools, namely, mobile phones, in the pre-service teachers' instruction. In the current research we call this pre-service teacher the 'leading pre-service teacher'.

This article describes three case studies related to the participants' instructional attitudes and decisions associat- ed with using mobile phones in mathematics teaching. The first case study is about one in-service teacher who collaborated with the researchers and the leading pre-service teacher to use mobile phones in her class. The second case study concerns the leading pre-service teacher who collaborated with the in-service teacher and the researchers to teach mathematics lessons using mobile phones, while the third case study involves 15 pre-service teachers who were experiment observers but did not use mobile phones in their teaching. Those pre-service teachers could have used mobile phones in their teaching but they were not obliged to do so, because neither all the mobile phones of those pre-service teachers nor those of the school students had java which is needed to make midlets work.

\section{B. Mathematical software and learning materials}

The middle school students worked with mobile phone software (midlets) that supports algebra and geometry learning. The midlets can be downloaded from Math4Mobile site of the Institute for Alternatives in Education that operates within the Faculty of Education at the University of Haifa [33]. To perform the activities assigned to them, the students used the algebraic midlets and various tools and technologies embedded in their mobile phones. The middle school students used mobile phones in tasks related to the linear and quadratic function.

\section{Data collecting tools}

Interviews with the teachers: We held one-hour semistructured interviews with the in-service teacher, the leading pre-service teacher and with the group of the other observer pre-service teachers. This happened three times during the academic year: at the beginning of the experiment, after three months and after it ended. The issues discussed in the interviews were related to the activity theory components and sub-issues associated with them, for example personal history and perceptions (related to the subject), the subject's perceptions of the conditions for the success of teaching mathematics with mobile phones (related to tool, rules, community and division of labor), and decisions and attitudes towards use of mobile phones in mathematics teaching (related to the object and outcome of experimenting teaching mathematics with mobile phones).

\section{Data analysis}

We used the constant comparison method [34] to arrive at categories related to the activity theory components. The constant comparison method is a process of inspection consisting of concept construction, through a constant comparison of emergent codes and the development of relationships among the concepts ([35], [36]). Here, it was applied keeping in mind the activity theory components and themes related to each of them. For example, we kept comparing each participant's sentences (given in the interview) which implied how division of labor and community rules were represented and influenced the participants' attitudes and decisions regarding the use of mobile phones in mathematics education. Doing so, we arrived at the themes related to the division of labor in our specific context: who should teach, who should prepare learning activities needed to be used for learning mathematics using mobile phones, who decides which tools to use in the mathematics classroom, who decides which mathematical material to cover in an academic year, etc. Furthermore, 
we looked for the values of the different themes in each one of the three case studies.

\section{E. Relevance of the data analysis to the setting and theme of the study}

The goal of the current study was to describe an activity theory model for teaching mathematics using mobile phones. One way to do so was to use the constant comparison method to arrive at themes and categories related to activity theory components when teaching mathematics with mobile phones. This analysis process has been followed in previous researches for similar goals. For example, Ref. [26] used it to analyze how students revised after writing center conferences in activity theory terms. Furthermore, Ref. [25] used it to explain how students' learning outcomes evolved from their online learning experiences, using activity theory contradictions. Moreover, Ref. [36] analyzed two individual teachers' experience of mathematics and explored, using activity theory, how these experiences impacted their teaching. In the three previous researches, as in the current one, the emphasis is on the individual interacting with an educational situation.

\section{FINDINGS}

At the beginning, we describe the activity system's elements regarding each of the three case studies in which this research involves: the in-service teacher's case, the leading pre-service teacher's case and the other observer pre-service teachers' case.

\section{A. The subject}

Two factors distinguish the subject: his/her history and his/her perceptions regarding the use of technology in teaching mathematics. Below we describe these factors regarding each subject in the current research.

The in-service teacher as subject

History: The in-service teacher has a history of using mathematical software in teaching mathematics. This history was not successful, for the students did have conceptual knowledge of the mathematical topics they learned, but they did not have appropriate procedural knowledge of these topics; therefore, they had great problems when they advanced to high school where teachers depended greatly on procedural knowledge.

Perceptions: The in-service teacher thinks that procedural knowledge of mathematical topics is essential for the students; thus, although she assumes that students enjoy learning using computers she thinks that this should not be done in every lesson or in the whole lesson. She also thinks that it is difficult to integrate real life into mathematics teaching and learning in middle or high school.

Leading pre-service teacher as subject

History: The leading pre-service teacher took two courses focusing on the use of technology in the classroom, where one of them (didactics of teaching mathematics) focused on technology use in mathematics teaching. More specifically, he performed different tasks on this use, so he was aware of the advantages of using technology in mathematics education. In addition, the leading preservice teacher participated in the meetings held between the two researchers and in which they discussed the experiment advancement, the activities that should be carried out and students' learning using mobile phones.
Perceptions: The leading pre-service teacher thinks that technology makes teachers' instruction and students' learning easier. Furthermore, he thinks that working with mathematical software adds a visual aspect to students' mathematical investigations, which assists the students in arriving at mathematical relations, so technology should be used in mathematics teaching. In addition, he argues that the mobile phone is already in students' hands, and they like working with it, so it would better be utilized as a learning tool.

Observer pre-service teachers as the subject

History: The pre-service teachers' history is similar to that of the leading pre-service teacher, but they did not participate in the meetings with the researchers.

Perceptions: The observer pre-service teachers' perceptions regarding the use of technology in mathematics education were similar to those of the leading pre-service teacher, but they did not mention the idea of utilizing mobile phones for its availability in students' hands.

\section{B. The object}

The difference between the object as the in-service teacher and the object as the pre-service teachers (including the leading one) lies in the fact that the object of the in-service teacher involved her own class, where she was responsible of covering all the material in the mathematics book, as well as of having a good level of students' achievement in mathematics. On the other hand, the object of the pre-service teachers was a classroom in which they were being trained, where they did not have the responsibilities that the in-service teacher had.

\section{The tool}

All the subjects emphasized the need that at least half of the learners in a class should be equipped with mobile phones. In addition, all the subjects pointed out that the school administration should be flexible and allow students to use mobile phones in mathematics classes.

\section{The community}

The community in the case of the in-service teacher as the subject comprised the school in which the teacher taught. It included the teacher herself, the principal of the involved school, as well as the whole community of teachers. The community in the case of the leading preservice teacher, as well as in the case of the observer preservice teachers consisted of the community of the preservice teachers in the college where they studied, the instructor of the mathematics didactics course (the first author of this article) and the supervisor of the pre-service teachers in the college and the training school (the second author of this article). In addition, this community consisted of the in-service teacher who participated in the experiment and the students' school where the experiment was carried out.

\section{E. Division of labor and community rules}

In the case of the in-service teacher, the principal expected her to cover most of the mathematics book for grade 9. More specifically she was expected to prepare her students for the secondary school mathematics, as well as to make her students have high achievement in mathematics.

It was not expected from the in-service teacher to prepare additional learning materials for her students. It also 
was not expected from her to use computers or mobile phones in her mathematics teaching. At the same time, the school principal expected her to cooperate with the supervisor and his pre-service teachers and start using mobile phones in her teaching on Mondays, when they are present in her lessons.

In the case of the leading pre-service teacher, the researchers advised him to cooperate with the in-service teacher to prepare learning materials that suit the mobile phone environment. The researchers also advised him to teach those learning materials to grade 9 students alone or with the in-service teacher.

In the case of the observer pre-service teachers, it was expected that they prepare additional learning materials for the students. They also were required by their supervisor to use electronic tools (for example videos, PowerPoint presentations, electronic spreadsheets, applets) in their teaching, but not necessarily mobile phones.

The in-service teacher and the leading pre-service teacher emphasized the need for appropriate mathematical activities, so the students will be seriously involved in learning mathematics and not distracted by mobile phones.

\section{F. Outcome}

Tables 1, 2 and 3 describe the participants' attitudes towards and decisions regarding the use the mobile phone in mathematics teaching in the three cases. After having analyzed the collected data using the constant comparison method, we arrived at four themes that comprise the participants' attitudes and decisions: Place of use, frequency of use, target of use and role of the tool. The tables display the values of the previous themes in the three research cases. We chose this display format to present in-service and pre-service teachers' attitudes and decisions more clearly and neatly.

\section{DISCUSSION}

Figure 3 shows the components of each element of the activity system as related to teaching mathematics using mobile phones.

Figure 3 indicates that two characteristics distinguish the subject: his/her history and his/her perceptions. These characteristics influence the outcome of subject's activity, in our case the attitudes and decisions regarding the use of mobile phones in mathematics teaching. This influence of the history and perceptions of teachers is acknowledged in the literature. For example Ref. [38] identified experience (one facet of one's history) and sense of efficacy to implement the innovation as influencing teachers' attitude. Moreover, the educational history of the subject has been identified as an important factor influencing the student resistance to the use of new technological tools for learning (Ref. [39], as reported in Ref. [23]), but in our case it influenced the teacher's attitudes and decisions regarding mobile phone use in mathematics teaching. Furthermore, the above findings agree with other studies' findings about the factors that influence teachers' attitudes. For example, Ref [40] identified teachers' perceptions of the importance and difficulty of implementing innovations as influencing teachers' attitude towards this implementation.

The community also influenced the participants' decisions and attitudes towards integrating technology into the
TABLE I.

ATTITUDES AND DECISIONS REGARDING MOBILE PHONE USE IN MATHEMATICS TEACHING: THE CASE OF THE IN-SERVICE TEACHER

\begin{tabular}{|l|l|}
\hline \multicolumn{1}{|c|}{ Aspect } & \multicolumn{1}{c|}{ Attitudes and decisions } \\
\hline Place of use & Inside the classroom \\
\hline Frequency of use & Not in every lesson and not in the whole lesson \\
\hline Target of use & $\begin{array}{l}\text { To help students discover mathematical rela- } \\
\text { tions }\end{array}$ \\
\hline Role of the tool & It should be secondary to the role of teacher \\
\hline
\end{tabular}

TABLE II.

ATTITUDES AND DECISIONS REGARDING MOBILE PHONE USE IN THE MATHEMATICS TEACHING: THE CASE OF LEADING PRE-SERVICE TEACHER

\begin{tabular}{|l|l|}
\hline \multicolumn{1}{|c|}{ Aspect } & \multicolumn{1}{c|}{ Attitudes and decisions } \\
\hline Place of use & Inside as well as outside the classroom \\
\hline Frequency of use & In every lesson \\
\hline Target of use & $\begin{array}{l}\text { Introducing a new mathematics topic, investi- } \\
\text { gating and discovering mathematics relations } \\
\text { or summarizing with the students the conclu- } \\
\text { sions of their investigation }\end{array}$ \\
\hline Role of the tool & It has a main role like the teacher \\
\hline
\end{tabular}

TABLE III.

ATTITUDES AND DECISIONS REGARDING MOBILE PHONE USE IN THE MATHEMATICS TEACHING: THE CASE OF OBSERVER PRE-SERVICE TEACHERS.

\begin{tabular}{|l|l|}
\hline \multicolumn{1}{|c|}{ Aspect } & \multicolumn{1}{c|}{ Attitudes and decisions } \\
\hline Place of use & $\begin{array}{l}\text { Mostly inside the classroom, but sometimes } \\
\text { outside the classroom }\end{array}$ \\
\hline Frequency of use & In every lesson \\
\hline Target of use & $\begin{array}{l}\text { To introduce a new mathematical topic or to } \\
\text { summarize it }\end{array}$ \\
\hline Role of the tool & it complements the teacher's role \\
\hline
\end{tabular}

mathematics classroom. Community is reported to influence the subject's activity in other researchers, where the subject can be the students or the teachers. Ref. [32] found that the involvement of the school principal influenced students' learning with mobile phones. Ref. [41] found that the need of leadership involvement could hinder the integration of interactive boards into the classroom. In our current experiment, the pre-service teachers were influenced by their instructors' activity, so they had more favorable attitude towards mobile phone integration into their teaching than that of the in-service teacher who was not influenced as much as the pre-service teachers by the researchers.

Rules and division of labor also are important factors influencing the subjects' decisions and attitudes towards mobile phone integration into their mathematics teaching. Up to the time of our experiment, there were no declared national rules in the Israeli schools that impose using technology in the mathematics classroom, so teachers did not find themselves obliged to perform such integration. Furthermore, mathematics teachers were not expected to prepare technology based learning materials for their classrooms; especially mobile phone-based learning materials. This made them reluctant to integrate new technology into their classrooms; an act that requires them to prepare appropriate learning material.

Division of labor influence on the subject attitude, as described above, is also mentioned by Ref. [42]. Moreo- 
PAPER

In-SERViCe ANd Pre-Service Middle School Mathematics Teachers' Attitudes ANd Decisions Regarding ...

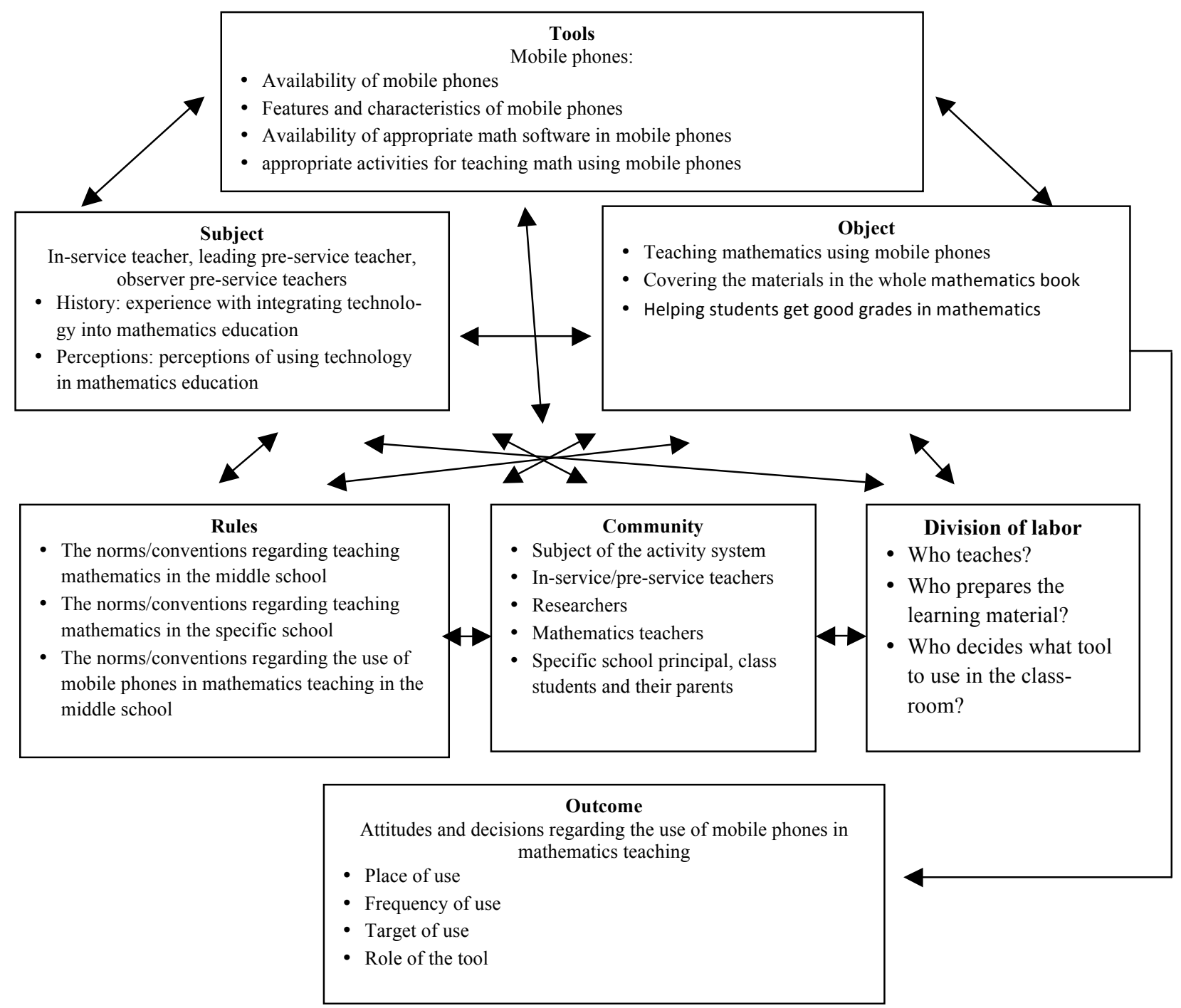

Figure 3. Components of the activity system's elements as related to teaching mathematics using mobile phones.

ver, Ref. [43] argued that changing the division of labor between the teacher and students would change their attitudes towards their roles in the classroom. Here, the inservice teacher changed her attitude towards mobile phone use in mathematics teaching in spite of the traditional rules and division of labor prevailing in her class. This change happened due to the new experience of the inservice teacher as a participant in an experiment which considers mobile phones as teaching and learning tools in the mathematics classroom. The change led to new division of labor that the mobile phone helped attain because it encouraged a more active role of the students (see for example Ref. [44]).

As for the attitudes and teaching decisions of the subjects at the end of the experiment, they differed among the subjects in the four aspects: place of the educational use of mobile phones, frequency of the mobile phone use in mathematics teaching, target of mobile phone use and tool role. Regarding the place of use, the leading pre-service teacher thought that mobile phones should be used inside the classroom as well as outside the classroom. This attitude could have been developed as a consequence of his several meetings with the researchers, where they emphasized the great potential of mobile phone in mathematics learning, especially outside the classroom, where the ideas of the outside activities developed. The observer preservice teachers thought that mobile phones should be used mostly inside the classroom, but sometimes outside the classroom. This attitude could have been developed because they witnessed the activities carried out by the students outside the classroom, and saw their enthusiasm to carry out such activities. At the same time, they were not actually involved in developing these activities. This lack of involvement affected their attitude towards mobile phone use in education [45]. With regard to the in-service teacher, she thought that mobile phones would better be used inside the classroom. Probably, her responsibility for covering the learning material discouraged her from considering the option of the outside use of mobile phones. This attitude of the in-service teacher goes side by side with the expectations of her community, specifically the school principal and the parents of the students.

We find differences in the subjects' attitudes regarding the frequency of use too. All the pre-service teachers, including the leading one, thought that mobile phones should be used in every mathematics lesson, while the inservice teacher thought that such use should not be in every lesson or in the whole lesson. Here too, the commu- 
nity affected this difference in attitudes, where the preservice teachers were influenced by their instructors (the researchers) whose instruction emphasized the role of technology in mathematics education, while the in-service teacher was influenced by her community, where this community, as mentioned above, did not expect mobile phones to be used in mathematics teaching. The subjects' history also caused the difference in their attitudes towards the frequency of mobile phone use in mathematics teaching, which was described above.

As for the target of use, the in-service teacher was impressed by the features and characteristics of mobile phones that were made apparent during its use in the mathematics teaching during the experiment. The features included the illustration abilities enabled by the mobile phone midlets, while the characteristics included the mobile phone availability and its ease of use. Therefore, she adopted the target of discovering mathematical relations using mobile phones. On the other hand, the observer preservice teachers, who did not participate practically in carrying out mobile phone activities, thought that mobile phones could be used in the math lesson for just introductory and summary purposes. As for the leading pre-service teacher, who carried out the actual activities with the students, he could see the diverse advantages of mobile phones, which convinced him of the varied teaching targets using it; i.e. introducing a new mathematics topic, investigating and discovering mathematical relations or summarizing with the students the results of their investigation. This picture of the subjects' attitude towards the target of using mobile phones in mathematics teaching was also influenced by the subjects' history, rules, division of labor, and community, as described above.

If we look at the subjects' attitudes towards the role of mobile phones in mathematics teaching, we find different attitudes, where the leading pre-service teacher had the most favorable attitude regarding this role, saying that mobile phones have a main role like the teacher, while the in-service teacher had the least favorable attitude, saying that they should be secondary to the role of teacher. The observer pre-service teachers had an attitude between the previous two attitudes, saying that mobile phones complement the teacher's role. The previous three different attitudes consider the role of teacher as a main one, which agrees with previous studies. For example Ref. [46] described the role of the teacher as critical when working with technology in the classroom, while Ref. [47] emphasized the complementary nature of the role of technologies in subject teaching.

The above influences indicate some contradictions within the activity which hinder or slow the process of meeting the objective of the activity; i.e. using mobile phones in mathematics teaching. One contradiction was between the subject and the tool in the case of the inservice teacher. This contradiction occurred as a consequence of the teacher's unsuccessful history in using technology in mathematics teaching. Another contradiction occurred between division of labor and the subject, in the case of the in-service teacher, because she was not expected by the school community to prepare learning materials for her classroom. Both of the previous two kinds of contradictions were reported by Ref. [22] to slow the integration of ICT into a Turkish school. Here too, they could have slowed to the minimum the use of mobile phones in mathematics teaching if the in-service teacher did not receive help from the researchers and the leading pre-service teacher. In other words, these contradictions were lessened by the collaboration of the in-service teacher with the researchers at the beginning, and afterwards with the leading pre-service teacher. This collaboration made the teacher aware of the possibilities of mobile phone use in mathematics teaching for students' learning. Thus, she came to realize the worthiness of preparing new appropriate learning materials to make the students utilize the potentialities of mobile phones in their mathematics learning. Moreover, the new experience lessened the negative impact of the previous teaching experience of the inservice teacher with technology.

Other contradictions can be found in the activity system described above. One such contradiction is between the community and the tool, where some members of the community, in our case the principal, prohibit mobile phone use in the school area including the classrooms. This contradiction was solved from the beginning when the researchers met the principal and discussed mobile phone use as a learning tool in the 9th grade mathematics classroom. Another contradiction is between the tool and the object, where the in-service teacher and pre-service mathematics teachers thought that using tools in the mathematics classrooms could slow the teaching process of the mathematical topics, which made them reluctant to use tools in their classroom. The contradiction in which the tool is a component is reported in other researches but for different reasons. For example, Ref. [48], reported a case where the teacher considered the computer as suitable for lower level cognitive skills, whereas he wanted to advance higher levels of these skills. The contradiction in our research in which the tool was involved was lessened when the teacher and the pre-service teachers watched the researchers utilize mobile phones successfully to introduce complicated mathematical topics in relatively short time.

All the contradictions are shown in Figure 4, represented in the dashed lines, but it is important to note that the two contradictions in the case of the subject (the in-service teacher) were present more than in the other two cases.

These contradictions were solved primarily by the mediation of the community, especially by leading members in the community (the researchers and the school principal), which indicates the importance of the role of the leading members in the community in maintaining the momentum throughout the experiment [49]. In our case, the leading members mediated and overcame the educational contradictions that arose as a consequence of introducing new technological tool in teaching. In other words, the attitudes and decisions of the leading members of the community concerning mobile phone use in teaching mathematic made them develop an initiative that influenced in different ways, according to the specific condi-

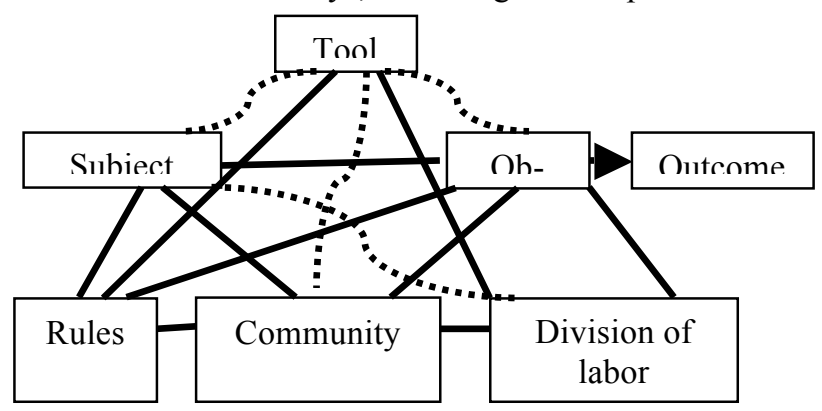

Figure 4. Contradictions in the case of in-service teacher. 
tions of the community, the participating in-service/preservice teachers' attitudes and decisions regarding mobile phone use in teaching mathematics.

\section{VIII.CONCLUSIONS}

The research goal was to examined decisions and toward teaching mathematics when using mobile phones. It was found that the teacher's history related to using technologies in teaching had an impact on his/her attitude and decisions regarding utilizing new technologies in teaching. This makes it necessary to consider teachers' history in implementing technology in teaching before asking them to do so. It also means preparing these teachers for technology integration, so their attitudes and decisions regarding teaching mathematics with the mobile phone are considered and treated. This could be done especially through reflection on the participating teachers' experiences [50]. Mathematics teachers will not integrate successfully technology into their classes unless they change their historical negative attitudes towards this integration, which could also be done through the guidance of educational technology experts [51].

Other factors which influenced the participants' attitudes and decisions were: teachers' perceptions of using technologies in teaching, teacher's community, rules of using technologies in teaching mathematics and division of labor, for example who decides which technologies to use in teaching and who should prepare the learning material for students. These factors were also described elsewhere as influencing students' learning of mathematics with mobile phones [32], where another theory of analyzing data was used, namely, the grounded theory. This emphasizes the prevalence of these factors as influencing the integration of mobile phones (and we suppose technology in general) into the learning and teaching of mathematics.

As for the pre-service teachers who participated in the research, it can be concluded that their history, together with the characteristics of their school community made them more apt to accept mobile phones as teaching tools. They have been exposed in their preparation as future teachers to new educational technologies and at the same time were part of a community in which the leading members initiated projects that utilized such technologies. They also were required to utilize such technologies in the classroom. So, history, community and rules made the difference in the activity outcome related to the different subjects. The community, especially its leading members, also mediated and helped overcome the activity contradictions that arose throughout the experiment regarding the teaching processes in and/or out of the mathematics classroom. This emphasizes that school conditions and school leadership, manifested by the mobile phone project leadership represented by the researchers, are key issues in efforts to change instruction [52] and enrich it with new technologies in our case.

\section{REFERENCES}

[1] Cobcroft, R., Towers, S., Smith, J., \& Bruns, A. (2006). Mobile learning in review: Opportunities and challenges for learners, teachers, and institutions. In Proceedings of Online Learning and Teaching (OLT) Conference 2006 (pp. 21-30). Queensland University of Technology, Brisbane. Available from http://eprints.qut.edu.au/5399/1/5399.pdf

[2] Botzer, G. \& Yerushalmy, M. (2007) Mobile Applications for Mobile learning. In Proceedings of the Cognition and Exploratory
Learning in the Digital Age (CELDA). December. Algarve, Portugal.

[3] Kizito, R. N. (2012). Pretesting Mathematical Concepts with the Mobile Phone: Implications for Curriculum Design. The international review of research in open and distance learning, 13 (1). http://www.irrodl.org/index.php/irrodl/article/view/1065/2075

[4] Daher, W. (2010a). Building mathematical knowledge in an authentic mobile phone environment. Australasian Journal of Educational Technology, 26(1), 85-104.

[5] Daher, W. \& Baya'a, N. (2012). Characteristics of middle school students learning actions in outdoor mathematical activities with the cellular phone. Teaching Mathematics and its Applications: An International Journal of the IMA, 31 (3), 133-152. http://dx.doi.org/10.1093/teamat/hrr018

[6] Baya'a, N. \& Daher, W. (2009). Learning mathematics in an authentic mobile environment: the Perceptions of Students. International Journal of Interactive Mobile Technologies, 3 (Special Issue, IMCL 2009), 6-14. http://online-journals.org/ijim/article/view/813/970

[7] Daher, W. (2009). Students' perceptions of learning mathematics with cellular phones and applets. International Journal of Emerging Technologies in Learning, 4(1), 23-28.

[8] Daher, W. (2011a). Learning mathematics in the mobile phone environment: Students' emotions. Journal of Interactive Learning Research, 22(3), 357-378.

[9] Daher, W. (2010b). Mathematics learning community flourishes in the cellular phone environment. International Journal of Mobile and Blended Learning (IJMBL), 2(2), 1-17. http://dx.doi.org/10.4018/jmbl.2010040101

[10] Daher, W. (2011b). Building mathematics cellular phone learning communities. International Journal of Interactive Mobile Technologies (iJIM), 5(2), 9-16.

[11] So, S. (2008). A Study on the Acceptance of Mobile Phones for Teaching and Learning with a Group of Pre-service Teachers in Hong Kong. Journal of Educational Technology Development and Exchange, 1(1), 82-92.

[12] Litchfield, A.J., Dyson, L. E., Lawrence, E. \& Zmijewska, A. (2007). Directions for m-learning research to enhance active learning. In ICT: Providing choices for learners and learning. Proceedings ascilite Singapore 2007. http://www.ascilite.org.au/ conferences/singapore07/procs/litchfield.pdf

[13] Dyson, L.E., Litchfield, A., Lawrence, E., Raban, R., \& Leijdekkers, P. (2009). Advancing the m-learning research agenda for active, experiential learning: Four case studies. Australasian Journal of Educational Technology, 25(2), 250-267. Available from http://www.ascilite.org.au/ajet/ajet25/dyson.html

[14] Liu, T.C., Wang, H.Y., Liang, J.K., Chan, T.W., Ko, H.W. \& Yang, J.C. (2003). Wireless and mobile technologies to enhance teaching and learning. Journal of Computer Assisted Learning, $19(3), \quad 371-382 . \quad$ http://dx.doi.org/10.1046/j.0266-4909.2003. $\underline{00038 . x}$

[15] Ng, W., \& Nicholas, H. (2012). A framework for sustainable mobile learning in schools. British Journal of Educational Technology. 44 (5), 695-715. http://dx.doi.org/10.1111/j.14678535.2012.01359.x

[16] Armatas, C., Holt, D.M., \& Rice, M. (2005). Balancing the possibilities for mobile technologies in higher education. In Proceedings of the 22nd Annual Conference of the Australasian Society for Computers in Learning in Tertiary Education (ASCILITE): Balance, Fidelity, Mobility: Maintaining the Momentum? Brisbane (pp.27-35).

[17] Engestrom, Y. (2003). What is Activity Theory? Available from http://carbon.ucdenver.edu/ mryder/itc/act_dff.html

[18] Engeström, Y. (2001). Expansive learning at work: toward an activity theoretical reconceptualization. Journal of Education and Work, 14(1), 133-156. http://dx.doi.org/10.1080/13639080020 $\underline{028747}$

[19] Engeström, Y. (1987). Learning by expanding: An activitytheoretical approach to developmental research. Helsinki: Orienta-Konsultit.

[20] Centre for Activity Theory and Developmental Work Research. (2003-2004). The Activity System. http://www.edu.helsinki.fi/ activity/pages/chatanddwr/activitysystem 
[21] Sujan, M. A., Rizzo, A. \& Pasquini, A. (2002). Contradictions and critical issues during system evolution. In Proceedings of the 2002 ACM Symposium on Applied Computing, Madrid (pp.711-715). New York: ACM. http://dx.doi.org/10.1145/508791.508929

[22] Demiraslan, Y. \& Usluel, Y. K. (2008). ICT integration processes in Turkish schools: Using activity theory to study issues and contradictions, Australasian Journal of Educational Technology, 24(4), 458-474.

[23] Murphy, E. \& Rodriguez-Manzanares, M.A. (2008).Using activity theory and its principle of contradictions to guide research in educational technology. Australasian Journal of Educational Technology, 24(4), 442-457. http://www.ascilite.org.au/ajet/ajet24/ murphy.html

[24] Welch, G. (2006). Addressing the multifaceted nature of music education: an activity theory research perspective. In: Proceedings of the 21st Seminar on Research in Music Education (pp. 221229). Bali, Indonesia. Hong Kong Baptist University. http://www.imerc.org/papers/wells/rsme07.pdf

[25] Terantino, J.M. (2009). Transformational processes and learner outcomes for online learning: An activity theory case study of Spanish students. Unpublished doctoral dissertation. University of South Florida. http://scholarcommons.usf.edu/cgi/viewcontent.cgi ?article $=1046 \&$ context $=$ etd $\&$ sei-redir $=1 \#$ search $=\% 22$ activity $\% 20$ theory\%20educational $\% 20$ processes $\% 22$

[26] Van Horne, S.A. (2011). An activity-theory analysis of how college students revise after writing center conferences. Unpublished doctoral dissertation. University of Iowa. Available from http://ir.uiowa.edu/cgi/viewcontent.cgi?article $=2571 \&$ context $=$ etd

[27] LaCroix, L.N. (2011). Mathematics learning through the lenses of cultural historical activity theory and the theory of knowledge objectification. In M. Pytlak, T. Rowland, \& E. Swoboda (Ed.), Proceedings of the Seventh Congress of the European Society for Research in Mathematics Education (CERME7), Rzeszów, Poland, 2462-2471.

[28] [28] Radford, L. (2006). Elements of a cultural theory of objectification. Revista Latinoamericana de Investigación en Matemática Educativa, Special issue on semiotics, culture and mathematical thinking, pp. 103-129.

[29] [29] Radford, L. (2007). Towards a cultural theory of learning. In Pitta-Pantazi, D., \& Philippou, G. (Eds.), Proceedings of the Fifth Congress of the European Society for Research in Mathematics Education (CERME - 5) (pp. 1782-1797). Larnaca, Cyprus, CDROM, ISBN - 978-9963-671-25-0.

[30] Radford, L. (2008). The ethics of being and knowing: Towards a cultural theory of learning. In L. Radford, G Schubring, \& F. Seeger (Eds.), Semiotics in mathematics education: Epistemology, history, classroom and culture (215-234). Rotterdam: Sense Publishers.

[31] Engeström, Y. (1993). Developmental studies of work as a testbench of activity theory: The case of primary care medical practice. In S. Chaiklin, \& J. Lave (Eds.), Understanding practice: Perspectives on activity and context (pp. 64-103). Cambridge, England: Cambridge University Press. http://dx.doi.org/10.1017/ CBO9780511625510.004

[32] Baya'a, N., \& Daher, W. (2010). Middle school students' learning of mathematics using mobile phones: Conditions and consequences. Journal of Interactive Learning Research, 21(1), 1-25. http://www.editlib.org/p/29401

[33] Yerushalmy, M., \& Weizman, A. (2007). Math4Mobile mobile environment. The University of Haifa. http://www.math4mobile.com

[34] Glaser, B.G., \& Strauss, A. (1967). Discovery of grounded theory: Strategies for qualitative research. Chicago, IL: Aldine.

[35] Athens, L. (2010). Naturalistic inquiry in theory and practice. Journal of Contemporary Ethnography, 39 (1), 87-125. http://dx.doi.org/10.1177/0891241609343663

[36] Fran, S. M. (2013). The Constant Comparative Analysis Method Outside of Grounded Theory. The Qualitative Report, 18, 1-25.

[37] Page, S., \& Clark, J.A. (2010). Experiences of learning and teaching mathematics: Using activity theory to understand tensions in practice. In L. Sparrow, B. Kissane, \& C. Hurst (Eds.). Proceedings of the 33rd annual conference of the Mathematics Education Research Group of Australasia: Shaping the future of mathematics education, 2, 462-468. Fremantle, WA: MERGA.
[38] Guskey, T.R., \& Gates, S.L. (1986). Synthesis of research on the effects of mastery learning in elementary and secondary classrooms. Educational Leadership, 43(8), 73-80.

[39] Blin, F. (2005). CALL and the development of learner autonomy: An activity theoretical study. Unpublished doctoral dissertation, Institute of Educational Technology, The Open University, UK. http://www.dcu.ie/ blinf/BlinThesis.pdf

[40] Sparks, G.N. (1983).Synthesis of research on staff development for effective teaching. Educational Leadership, 41(3), 65-72.

[41] Navarrete, C. (2011). Identifying affordances and barriers to student-centered, collaborative learning in the integration of interactive Whiteboard Technology. In M. Koehler, \& P. Mishra (Eds.), Proceedings of Society for Information Technology \& Teacher Education International Conference 2011 (pp. 29963001). Chesapeake, VA: AACE.

[42] Martinez, R., Cheng, A.S., Smith, K., Smith, M., \& Yoon, S. (2002). Indiana University Instructional Systems Technology (IST) graduate student attitudes towards group work. Y520: Strategies for educational inquiry Section 5982, Fall 2002 Group Project Reports. http://www.indiana.edu/ educy520/sec5982/week 15/ rmacksmssy.pdf

[43] Kollias, V., Mamalougos, N., Vamvakoussi, X., Lakkala, M., \& Vosniadou, S. (2005). Teachers' attitudes to andbeliefs about webbased collaborative learning environments in the context of an international implementation. Computers and Education, 45(3), 295315. http://dx.doi.org/10.1016/j.compedu.2005.04.012

[44] Batista, S.C.F, Behar, P.A. \& Passerino, L. (2012). Pedagogical use of cell phones in Calculus I: Advantages and difficulties. International Journal on New Trends in Education and their implications (IJONTE), 3, 1-14.

[45] Stokmans, M.J.W. (2001). The effect of involvement on the reading attitude-behavior relationship. In A.J. Scott (Ed.), XXVI Annual Colloquium on Research in Economic Psychology: Environment and Wellbeing (pp. 285-290). Bath, UK: University of Bath.

[46] Clements, D.H., \& Nastasi, B.K. (1993). Electronic media and early childhood education. In B. Spodek (Ed.), Handbook of research on the education of young children (pp. 251-275). New York, NY: Macmillan

[47] Hennessy, S., Ruthven, K. \& Brindley, S. (2005). Teacher perspectives on integrating ICT into subject teaching: commitment, constraints, caution and change. Journal of Curriculum Studies, 37 (2), 155-192. http://dx.doi.org/10.1080/0022027032000276961

[48] Hardman, J. (2005). An exploratory case study of computer use in a primary school mathematics classroom: New technology, new pedagogy? Perspectives in Education, 23(4), 99-111.

[49] Herrington, J., Mantei, J., Herrington, A., Olney, I. W. \& Ferry, B. (2008). New technologies, new pedagogies: mobile technologies and new ways of teaching and learning, In R. Atkinson \& C. McBeath (Eds), Annual Conference of the Australasian Society for Computers in Learning in Tertiary Education, 2008 (pp. 419-427). Melbourne, Australia: Deakin University.

[50] Carlson, S. \& Gadio, C.T. (2002). Teacher Professional Development in the Use of Technology. In W. Haddad, and A. Drexler, (Eds), Technologies for Education, pp. 118-132. Paris: UNESCO.

[51] [Baya'a, N., Daher, W. \& Khalil, R. (2009). The role of the ICT coordinator in school. Jamaea'a, 13, 257-285.

[52] Spillane, J., Halverson, R., Diamond, J. (2004). Towards a Theory of School Leadership Practice: Implications of a Distributed Perspective. Journal of Curriculum Studies, 36 (1), 3-34. http://dx.doi.org/10.1080/0022027032000106726

\section{AUTHORS}

W. Daher is affiliated with An-Najah National University, Nablus, Palestine and with Al-Qasemi Academic College of Education, Baqa, Israel (e-mail: wajeehdaher@gmail.com).

N. Baya'a is affiliated with Al-Qasemi Academic College of Education, Baqa, Israel (bayaan@qsm.ac.il)

Submitted 28 March 2014. Published as resubmitted by the authors 14 October 2014. 